\title{
Zjawisko reelekcji prezydenta miasta w świetle wyników badań exit poll z wyborów samorządowych w Bielsku-Białej
}

\begin{abstract}
Streszczenie: Celem artykułu jest określenie uwarunkowań reelekcji prezydenta miasta za pomocą badań sondażowych typu exit poll zrealizowanych w dniu elekcji samorządowych z roku $2006(\mathrm{n}=1769)$ i z roku $2014(\mathrm{n}=1160)$.

Analizy wykazały istotne statystycznie związki między głosowaniem na inkumbenta a wiekiem i kategorią społeczno-ekonomiczną wyborców, deklarowanymi przez nich motywacjami głosowania w wyborach prezydenta miasta (szczególnie jeżeli chodzi o deklarację motywu dokonań) oraz poziomem wykazywanej przez głosujących niechęci wobec zmian. Badania nie ujawniły natomiast związków między głosowaniem za reelekcją a poziomem wiedzy politycznej.
\end{abstract}

Słowa kluczowe: reelekcja, wybory lokalne, zachowania wyborcze

\section{Uwagi wstępne}

Choć zjawisko ponownego wyboru polityka na to samo stanowisko interesuje naukowców przynajmniej od końca lat 30. XX wieku (zob. Hyneman, 1938), to badania nad reelekcją na poziomie wyborów lokalnych (gminnych) należy uznać za względną nowość - poważniejsze studia na ten temat pojawiły się bowiem dopiero w XXI wieku.

Zjawisko reelekcji w wyborach lokalnych analizuje się przede wszystkim w aspekcie ponownego wyboru włodarzy gmin, gdyż to właśnie tych aktorów społecznych, a nie radnych, traktuje się jako głównych architektów polityki lokalnej (zob. np.: Tybuchowska-Hartlińska, 2012, s. 126).

Podobnie jak w przypadku wyborów szczebla centralnego (tj. wyborów prezydenta kraju, wyborów parlamentarnych) lub regionalnego (np. wyborów stanowych w USA), zjawisko reelekcji na poziomie lokalnym (gminnym) rozpatruje się głównie pod kątem uwarunkowań i przyczyn. Tak też uczyniono w niniejszym artykule. Do określania korelatów 
i ewentualnych powodów wyboru prezydenta miasta na kolejną kadencję nie posłużono się jednak analizą danych zastanych, tak jak jest to w zdecydowanej większości opracowań na temat reelekcji, lecz badaniem exit poll polegającym na ankietowaniu losowo wybranych wyborców opuszczających lokale wyborcze. Prezentowany artykuł będzie zatem opisywał uwarunkowania i wskazywał możliwe przyczyny reelekcji „od strony głosujących", a więc uwzględniając ich deklaracje, cechy społeczno-demograficzne oraz świadomościowe, co jest możliwe wyłącznie dzięki zastosowaniu metody surveyowej.

Szczegółową prezentację wyników należy jednak poprzedzić krótkim omówieniem potencjalnych skutków reelekcji oraz rekapitulacją głównych wniosków, jakie literatura przedmiotu dostarcza na temat uprzywilejowanej pozycji polityków ubiegających się o reelekcję i jej uwarunkowań na poziomie lokalnym.

\section{Pozytywy i zagrożenia reelekcji}

W tle zainteresowania naukowców szczegółową problematyką uwarunkowań i przyczyn reelekcji znajdują się rozważania o ogólniejszym, systemowym charakterze. Zawierają się one w pytaniu o ewentualne pozytywy i zagrożenia wiążące się z ponownym wyborem polityka na to samo stanowisko.

Autor niniejszego artykułu nie znalazł jakiegokolwiek empirycznego opracowania, które wskazywałoby na ewentualne pozytywy lub negatywy reelekcji, co jest zrozumiałe, biorąc pod uwagę fakt, że rozważając wspomniany problem badacze poruszają się $\mathrm{w}$ obszarze imponderabiliów. Analiza skutków interesującego nas fenomenu będzie miała zatem charakter teoretyczny.

Niewątpliwie do pozytywów reelekcji zaliczyć należy kumulację doświadczenia. Dzięki doświadczeniu zdobytemu w poprzednim okresie urzędowania, polityk może bowiem lepiej wykonywać swoje obowiązki. Za zaletę reelekcji należy również uznać możliwość ponownie wybranej władzy kontynuowania prac nad projektami, których realizacja, z obiektywnych przyczyn, musi obją́ swym zasięgiem czasowym więcej niż okres jednej kadencji.

Do zagrożeń związanych z reelekcją będzie natomiast należeć przede wszystkim zjawisko erozji władzy, oznaczająca spadek racjonalności decyzji kierowniczych oraz obniżenie woli ich urzeczywistniania (Ko- 
zielecki, 1986), co tłumaczy się przede wszystkim starzeniem się osób posiadających władzę i rutynizacją ich działań, a także charakterem motywacji kratycznej (posiadanie władzy dla samego władania i dążenie do ciągłego poszerzania jej zakresu).

Za drugie potencjalne zagrożenie wiążące się z reelekcją należy uznać proceder polityzacji budżetu i instytucji publicznych, a więc prowadzenie przez rządzących polityki fiskalnej i wykorzystywanie środków publicznych oraz podległych im instytucji w taki sposób, by zapewnić sobie wybór na kolejną kadencję. Fakt kształtowania polityki fiskalnej w celu zapewnienia reelekcji został już zresztą udokumentowany badaniami i ujęty w ramy koncepcji political budget cycle (ewentualnie electoral budget cycle), o której wspomina się przede wszystkim w literaturze ekonomicznej (zob. m.in. Brender, Drazen, 2008).

Trzecim negatywnym zjawiskiem wynikającym z reelekcji może być zniechęcanie obywateli do partycypacji politycznej (zarówno w wymiarze uczestnictwa wyborczego, jak i kandydowania w wyborach), jako konsekwencji przekonania o braku jakichkolwiek szans na zmianę władzy.

Katalog zalet i wad reelekcji może być oczywiście uzupełniony o wiele innych elementów. Nie stanowi to jednak celu niniejszego artykułu.

\section{Przyczyny przewagi urzędującego polityka w wyborach}

Uprzywilejowana pozycja urzędujących polityków (tzw. inkumbentów ${ }^{1}$, ang. incumbent) w wyścigu o władzę jest faktem potwierdzonym badaniami naukowymi (Ansolabehere, Snyder, Stewart, 2000; Cox, Morgenstern, 1995; Erikson, 1971; Levitt, Wolfram, 1997). Wspomnianą prawidłowość obserwuje się zarówno w przypadku elekcji władz szczebla centralnego oraz regionalnego, jak i na poziomie wyborów lokalnych, na co zwracają uwagę również badacze polscy (Bukowski, Flis, Hess, Szymańska, 2011, s. 52).

Przewagę inkumbentów nad konkurentami w wyścigu o władzę tłumaczy się w literaturze przedmiotu przede wszystkim na dwa sposoby.

Po pierwsze, zwraca się uwagę, że urzędujący politycy, z racji spełnianych funkcji, przyciaggają większą uwagę mediów niż konkurenci (Mayhew, 1974; Mann, Wolfinger, 1980), co zapewnia im większą rozpoznawalność wśród wyborców, którym w większości przypadków daleko do

${ }^{1}$ Polski termin inkumbent zaproponował Jarosław Flis (w: Bukowski, Flis, Hess, Szymańska, 2011). 
modelu światłego obywatela dysponującego znaczącą wiedzą polityczną (zob. np.: Bartels, 1996).

Po drugie, przewagę inkumbentów nad konkurencją tłumaczy się możliwościami wydatkowania środków publicznych w taki sposób, by przypodobać się wyborcom (Cox, Morgenstern, 1993; King, 1991). Zależności między wysokością wydatków inwestycyjnych a szansami reelekcji są przy tym dobrze udowodnione naukowo (o czym więcej w następnym podrozdziale) i z ich występowania zdaje sobie najprawdopodobniej sprawę większość inkumbentów.

Omawiając zagadnienie przyczyn przewagi inkumbentów nad pretendentami w wyścigu o władzę, warto również wspomnieć o koncepcji klientelizmu, która, choć mniej popularna w literaturze przedmiotu na temat reelekcji, może w wielu przypadkach skutecznie wyjaśniać fenomen przewagi urzędujących polityków w wyborach na poziomie lokalnym (więcej. zob. Rutkowski, 2008). Oczywiście pretendenci również mogą spełniać funkcję patronów w układzie klientystycznym, ale fakt zajmowania urzędu przez inkumbentów zdecydowanie ułatwia budowanie relacji patron-klient, które, głównie dzięki przekazywaniu pieniędzy na kampanię, sprzyjają sukcesowi wyborczemu.

\section{Wcześniejsze badania nad uwarunkowaniami reelekcji włodarzy gmin na poziomie lokalnym}

Badacze zainteresowani reelekcją, niezależnie od analizowanego poziomu wyborów i ich rodzaju, skupiają się głównie na określeniu zależności między ponownym wyborem polityków na to samo stanowisko a polityką finansową gminy, przede wszystkim w zakresie wysokości deficytu budżetowego i struktury wydatków.

Analizy podejmowane na poziomie municypalnym w różnych krajach pokazują, że szanse prezydenta/burmistrza/wójta na reelekcję rzeczywiście zależą od wysokości wydatków inwestycyjnych gminy (Veiga, Veiga, 2007; Sakurai, Menezes-Filho, 2008), choć nie zawsze sprzyja jej już wzrost deficytu budżetowego (Brender, 2003; Caseette, Farvaque, 2013).

Relacje między reelekcją a cechami budżetu gmin interesują oczywiście także polskich badaczy, a ich obserwacje potwierdzają generalną zasadę, że wzrost wydatków infrastrukturalnych sprzyja reelekcji (Gendźwiłł, 2008; Piechota, 2013). 
Ciekawą perspektywę analizy uwarunkowań reelekcji włodarzy gmin w Polsce przyjął Sławomir Bartnicki, który wśród potencjalnych czynników warunkujących ponowny wybór inkumbentów uwzględnił nie tylko zmienne o charakterze ekonomicznym i demograficznym (liczba mieszkańców gminy, demograficzne cechy kandydata), ale także czynniki polityczne takie jak: liczba kandydatów ubiegających się o stanowisko prezydenta, burmistrza lub wójta oraz frekwencja wyborcza (Bartnicki, 2014). Na marginesie należy podkreślić, że S. Bartnicki przeanalizował dane dla wyborów z lat 2002, 2006 i 2010 oraz dla wszystkich 2475 gmin w kraju (stan na rok 2002), podczas gdy rodzimych badaczy najczęściej interesują wyłącznie wybory w miastach na prawach powiatu. S. Bartnicki zauważył między innymi, że w przypadku wszystkich polskich gmin najsilniej szanse reelekcji inkumbenta warunkuje liczba kandydatów w wyborach włodarza gminy, słabiej natomiast frekwencja, podczas gdy wielkość pozyskanych środków z UE miała niewielki wpływ na szanse reelekcji (Bartnicki, 2014, s. 11, 13).

\section{Szczególowe problemy badawcze, metodologia i materiał empiryczny}

W prezentowanym artykule zostaną udzielone odpowiedzi na następujące pytania badawcze:

1. Jak cechy społeczno-demograficzne warunkują głosowanie na inkumbenta?

2. Jakie powody głosowania na inkumbenta w wyborach prezydenta miasta deklarują jego wyborcy i czy różnią się oni pod tym względem od wyborców, którzy nie zagłosowali na inkumbenta?

3. Jak wyborcy inkumbenta oceniają jego pracę na stanowisku prezydenta miasta i czy różnią się oni pod tym względem od wyborców, którzy nie zagłosowali na inkumbenta?

4. Jak głosowanie na inkumbenta powiązane jest $\mathrm{z}$ wiedzą na temat specyfiki samorządu lokalnego, znajomością lokalnej sceny wyborczej i lokalnej polityki?

5. Jak głosowanie na inkumbenta powiązane jest $\mathrm{z}$ ogólną niechęcią wyborcy wobec zmian?

Jak już sygnalizowano, na potrzeby niniejszego artykułu wykorzystano badania exit poll, gdyż taki sposób zbierania danych umożliwiał opis uwarunkowań i przyczyn reelekcji ze względu na cechy osób podejmujących decyzje przy urnie wyborczej. Exit poll ma przy tym przewagę 
nad innymi rodzajami badań surveyowych, ponieważ w istotny sposób redukuje niebezpieczeństwo błędów towarzyszących innym typom sondaży, przede wszystkim dzięki lepszemu pokryciu populacji (więcej zob. Kubisz-Muła, 2013).

Analizowany materiał empiryczny obejmuje dane $\mathrm{z}$ dwóch badań exit poll, przeprowadzonych w Bielsku-Białej dnia 12 listopada $2006 \mathrm{r}$. (w trakcie pierwszej i zarazem jedynej tury wyborów samorządowych w wybranej gminie) oraz dnia 30 listopada 2014 r. (w trakcie drugiej tury wyborów). W obu badaniach próbę respondentów dobierano na zasadzie systematycznego doboru losowego (ankietowano co czwartą wychodzącą z lokalu osobę dorosłą). Punkty startowe dla ankieterów i lokale wyborcze również dobrano w sposób losowy. Zebrany materiał empiryczny obejmował 1769 ankiet w roku 2006 (z 16 komisji) i 1160 kwestionariuszy w roku 2014 (z 11 komisji) ${ }^{2}$.

W obu badaniach ankieta składała się z dwóch części. Część pierwsza wypełniana była przez ankietera i obejmowała różne pytania służące diagnozie uwarunkowań decyzji wyborczych. Część druga ankiety przeznaczona była do samodzielnego wypełniania przez respondenta i zawierała pytania o to, na kogo badany przed chwilą zagłosował w wyborach samorządowych, a także o to, jakie są jego preferencje partyjne (w oparciu o wybory do Sejmu RP). Następnie respondent wrzucał wypełnioną ankietę do pudełka imitującego urnę wyborczą.

Odpowiedzi na wskazane wyżej pytania badawcze będą udzielone albo w oparciu o oba zrealizowane sondaże exit poll, albo też z wykorzystaniem danych z jednego z nich, tj. albo z roku 2006, albo z roku 2014.

Pomimo tego, że obie analizowane elekcje dzieli okres dwóch kadencji, obserwacje poczynione w oparciu o dane z badań exit poll z roku 2006 i z roku 2014 można uznać za wysoce koherentne. W obu elekcjach inkumbentem był bowiem ten sam kandydat (Jacek Krywult), startujący z własnego komitetu o tej samej nazwie (tj. KWW Jacka Krywulta) i posiadający oficjalne, choć niezbyt eksponowane, poparcie tego samego ugrupowania politycznego (tj. PO). J. Krywult wygrał obie elekcje, przy czym w roku 2006 uczynił to w pierwszej turze, a w 2014 w turze drugiej.

${ }^{2}$ Autor pragnie podziękować dr Anecie Bąk za współpracę przy realizacji obu sondaży exit-poll. W roku 2006 błąd predykcji rezultatu zwycięzcy wyborów bez ważenia wyników (ważenie z uwzględnieniem struktury odmów) wyniósł 1,38 punkta procentowego, a w roku 2014 wyniósł 2,15 punkta procentowego. Wielkości te mieszczą się w granicach błędu statystycznego przy przyjęciu, zgodnie z konwencją nauk społecznych, 95\% poziomu ufności. 


\section{Społeczno-demograficzne uwarunkowania glosowania na inkumbenta}

Analizy materiału zebranego badaniami exit poll w 2006 i 2014 roku wykazuja, że zmiennymi warunkującymi poparcie inkumbenta w wyborach są wiek i powiązana z nim kategoria społeczno-ekonomiczna respondenta (przynależność do takich kategorii społeczno-zawodowych jak student, uczeń lub emeryt jest z oczywistych względów silnie zdeterminowana wiekiem). Nie są to jednak zależności zbyt mocne (patrz: wyniki testów chi-kwadrat i obrazujących siłę związku współczynnik V-Cramera w tabeli 1 i 2), a zarazem nie układają się w poszczególnych elekcjach według tego samego wzoru. Zmienne takie jak płeć i wykształcenie pozostają natomiast w omawianym kontekście bez znaczenia (wyniki testów nieistotne statystycznie).

Tabela 1

Wiek a głosowanie na inkumbenta lub pretendentów

\begin{tabular}{|c|c|c|c|c|c|c|c|}
\hline \multirow{2}{*}{ Rok 2006} & \multicolumn{6}{|c|}{ Kategoria wiekowa } & \multirow{5}{*}{$\begin{array}{c}\text { chi-kwa- } \\
\text { drat }=15,14 ; \\
\text { df }=5 ; \\
\text { p }<0,05 ; \\
\text { V-Crame- } \\
\text { ra }=0,10\end{array}$} \\
\hline & 18-25 lat & 26-35 lat & 36-45 lat & 46-55 lat & 56-65 lat & Pow. 65 lat & \\
\hline $\begin{array}{l}\text { Wyborcy } \\
\text { inkumbenta }\end{array}$ & $\begin{array}{l}76,62 \% \\
(\mathrm{n}=213)\end{array}$ & $\begin{array}{l}80,53 \% \\
(n=211)\end{array}$ & $\begin{array}{l}73,18 \% \\
(\mathrm{n}=161)\end{array}$ & $\begin{array}{l}74,93 \% \\
(n=275)\end{array}$ & $\begin{array}{l}77,05 \% \\
(\mathrm{n}=235)\end{array}$ & $\begin{array}{l}65,88 \% \\
(n=139)\end{array}$ & \\
\hline $\begin{array}{l}\text { Wyborcy } \\
\text { pretendentów }\end{array}$ & $\begin{array}{c}23,38 \% \\
(\mathrm{n}=65)\end{array}$ & $\begin{array}{l}19,47 \% \\
(\mathrm{n}=51)\end{array}$ & $\begin{array}{c}26,82 \% \\
(\mathrm{n}=59)\end{array}$ & $\begin{array}{c}25,07 \% \\
(\mathrm{n}=92)\end{array}$ & $\begin{array}{c}22,95 \% \\
(\mathrm{n}=70)\end{array}$ & $\begin{array}{l}34,12 \% \\
(\mathrm{n}=72)\end{array}$ & \\
\hline Razem & $100 \%$ & $100 \%$ & $100 \%$ & $100 \%$ & $100 \%$ & $100 \%$ & \\
\hline \multirow{2}{*}{$\begin{array}{c}\text { Rok } 2014 \\
\text { II tura }\end{array}$} & \multicolumn{6}{|c|}{ Kategoria wiekowa } & \multirow{5}{*}{$\begin{array}{c}\text { chi-kwa- } \\
\text { drat }=70,25 ; \\
d f=5 ; \\
\text { p }<0,05 ; \\
\text { V-Crame- } \\
\text { ra }=0,25\end{array}$} \\
\hline & 18-25 lat & 26-35 lat & $36-45$ lat & 46-55 lat & 56-65 lat & Pow. 65 lat & \\
\hline $\begin{array}{l}\text { Wyborcy } \\
\text { inkumbenta }\end{array}$ & $\begin{array}{c}43,24 \% \\
(\mathrm{n}=48)\end{array}$ & $\begin{array}{c}47,31 \% \\
(n=79)\end{array}$ & $\begin{array}{c}45,56 \% \\
(n=77)\end{array}$ & $\begin{array}{l}51,12 \% \\
(n=91)\end{array}$ & $\begin{array}{l}68,05 \% \\
(n=164)\end{array}$ & $\begin{array}{l}75,12 \% \\
(n=176)\end{array}$ & \\
\hline $\begin{array}{l}\text { Wyborcy } \\
\text { pretendentów }\end{array}$ & $\begin{array}{l}56,76 \% \\
(\mathrm{n}=63)\end{array}$ & $\begin{array}{l}51,69 \% \\
(\mathrm{n}=88)\end{array}$ & $\begin{array}{l}54,44 \% \\
(\mathrm{n}=92)\end{array}$ & $\begin{array}{c}48,88 \% \\
(\mathrm{n}=87)\end{array}$ & $\begin{array}{c}31,95 \% \\
(\mathrm{n}=77)\end{array}$ & $\begin{array}{l}24,79 \% \\
(n=58)\end{array}$ & \\
\hline Razem & $100 \%$ & $100 \%$ & $100 \%$ & $100 \%$ & $100 \%$ & $100 \%$ & \\
\hline \multirow{2}{*}{$\begin{array}{c}\text { Rok } 2014 \\
\text { I tura* }\end{array}$} & \multicolumn{6}{|c|}{ Kategoria wiekowa } & \multirow{5}{*}{$\begin{array}{c}\text { chi-kwa- } \\
\text { drat }=68,81 \\
\text { df }=5 \\
\text { p }<0,05 \\
\text { V-Crame- } \\
\text { ra }=0,27\end{array}$} \\
\hline & 18-25 lat & 26-35 lat & 36-45 lat & 46-55 lat & 56-65 lat & Pow. 65 lat & \\
\hline $\begin{array}{l}\text { Wyborcy } \\
\text { Inkumbenta }\end{array}$ & $\begin{array}{c}33,33 \% \\
(\mathrm{n}=30)\end{array}$ & $\begin{array}{l}40,14 \% \\
(n=57)\end{array}$ & $\begin{array}{c}43,45 \% \\
(n=63)\end{array}$ & $\begin{array}{c}47,44 \% \\
(n=74)\end{array}$ & $\begin{array}{l}65,93 \% \\
(n=149)\end{array}$ & $\begin{array}{l}69,52 \% \\
(n=146)\end{array}$ & \\
\hline \begin{tabular}{|l|} 
Wyborcy \\
pretendentów
\end{tabular} & $\begin{array}{c}66,67 \% \\
(\mathrm{n}=60)\end{array}$ & $\begin{array}{l}59,86 \% \\
(\mathrm{n}=85)\end{array}$ & $\begin{array}{l}56,65 \% \\
(n=82)\end{array}$ & $\begin{array}{l}52,56 \% \\
(\mathrm{n}=82)\end{array}$ & $\begin{array}{c}34,07 \% \\
(\mathrm{n}=77)\end{array}$ & $\begin{array}{c}30,48 \\
(\mathrm{n}=64)\end{array}$ & \\
\hline Razem & $100 \%$ & $100 \%$ & $100 \%$ & $100 \%$ & $100 \%$ & $100 \%$ & \\
\hline
\end{tabular}

* Na podstawie pytania zamieszczonego w sondażu z drugiej tury wyborów. Wyniki nie obejmują zatem reprezentacji osób, które nie udały się do drugiej tury wyborów.

Źródło: Badania własne exit poll 2006 i 2014. W analizie nie uwzględniono braków danych. 
Tabela 2

\section{Kategoria społeczno-zawodowa a głosowanie na inkumbenta}

\section{lub pretendentów}

\begin{tabular}{|c|c|c|c|c|c|c|c|}
\hline \multirow[b]{2}{*}{ Rok 2006} & \multicolumn{6}{|c|}{ Kategoria społeczno-zawodowa } & \multirow{5}{*}{$\begin{array}{c}\text { chi-kwa- } \\
\text { drat }=15,36 ; \\
\text { df }=5 ; \\
\text { p }<0,05 ; \\
\text { V-Crame- } \\
\text { ra }=0,10\end{array}$} \\
\hline & $\begin{array}{c}\text { Bezro- } \\
\text { botny }\end{array}$ & $\begin{array}{c}\text { Pracownik } \\
\text { fizyczny }\end{array}$ & $\begin{array}{c}\text { Pracownik } \\
\text { fizyczno- } \\
\text { umyslowy }\end{array}$ & \begin{tabular}{|c|} 
Pracownik \\
umyslowy
\end{tabular} & $\begin{array}{l}\text { Emeryt/ } \\
\text { rencista }\end{array}$ & $\begin{array}{c}\text { Uczeń/ } \\
\text { student }\end{array}$ & \\
\hline $\begin{array}{l}\text { Wyborcy } \\
\text { inkumbenta }\end{array}$ & $\begin{array}{l}77,14 \% \\
(n=54) \\
\end{array}$ & $\begin{array}{l}74,72 \% \\
(n=133)\end{array}$ & $\begin{array}{l}83,61 \% \\
(n=102)\end{array}$ & $\begin{array}{l}77,42 \% \\
(n=432)\end{array}$ & $\begin{array}{l}69,43 \% \\
(n=352)\end{array}$ & $\begin{array}{l}76,42 \% \\
(n=162)\end{array}$ & \\
\hline \begin{tabular}{|l|} 
Wyborcy \\
pretendentów
\end{tabular} & $\begin{array}{l}22,86 \% \\
(\mathrm{n}=16)\end{array}$ & $\begin{array}{l}25,28 \% \\
(n=45)\end{array}$ & $\begin{array}{l}16,39 \% \\
(n=20)\end{array}$ & $\begin{array}{l}22,58 \% \\
(\mathrm{n}=126)\end{array}$ & $\begin{array}{l}30,57 \% \\
(\mathrm{n}=155)\end{array}$ & $\begin{array}{l}23,58 \% \\
(\mathrm{n}=50)\end{array}$ & \\
\hline Razem & $100 \%$ & $100 \%$ & $100 \%$ & $100 \%$ & $100 \%$ & $100 \%$ & \\
\hline \multirow[b]{2}{*}{$\begin{array}{l}\text { Rok } 2014 \\
\text { II tura }\end{array}$} & \multicolumn{6}{|c|}{ Kategoria społeczno-zawodowa } & \\
\hline & $\begin{array}{l}\text { Bezro- } \\
\text { botny }\end{array}$ & $\begin{array}{c}\text { Pracownik } \\
\text { fizyczny }\end{array}$ & \begin{tabular}{|c|} 
Pracownik \\
fizyczno- \\
umyslowy
\end{tabular} & \begin{tabular}{|c|} 
Pracownik \\
umyslowy
\end{tabular} & $\begin{array}{l}\text { Emeryt/ } \\
\text { rencista }\end{array}$ & $\begin{array}{c}\text { Uczeń/ } \\
\text { student }\end{array}$ & \multirow{4}{*}{$\begin{array}{c}\text { chi-kwa- } \\
\text { drat }=68,51 ; \\
\text { df }=5 ; \\
\text { p }<0,05 ; \\
\text { V-Crame- } \\
\text { ra }=0,25\end{array}$} \\
\hline $\begin{array}{l}\text { Wyborcy } \\
\text { inkumbenta }\end{array}$ & \begin{tabular}{|c|}
$55,56 \%$ \\
$(\mathrm{n}=25)$
\end{tabular} & $\begin{array}{l}57,04 \% \\
(\mathrm{n}=77)\end{array}$ & $\begin{array}{l}\begin{array}{c}60,61 \% \\
(\mathrm{n}=60)\end{array}\end{array}$ & $\begin{array}{l}44,54 \% \\
(n=159)\end{array}$ & $\begin{array}{l}72,88 \% \\
(\mathrm{n}=258)\end{array}$ & $\begin{array}{c}40,00 \% \\
(\mathrm{n}=30)\end{array}$ & \\
\hline $\begin{array}{l}\text { Wyborcy } \\
\text { pretendenta }\end{array}$ & $\begin{array}{c}44,44 \% \\
(n=20)\end{array}$ & $\begin{array}{l}42,96 \% \\
(n=58)\end{array}$ & $\begin{array}{l}39,39 \% \\
(n=39)\end{array}$ & $\begin{array}{l}55,46 \% \\
(n=198)\end{array}$ & $\begin{array}{c}27,12 \% \\
(\mathrm{n}=96)\end{array}$ & $\begin{array}{c}60,00 \% \\
(n=45)\end{array}$ & \\
\hline Razem & $100 \%$ & $100 \%$ & $100 \%$ & $100 \%$ & $100 \%$ & $100 \%$ & \\
\hline \multirow[b]{2}{*}{$\begin{array}{l}\text { Rok } 2014 \\
\text { I tura* }\end{array}$} & \multicolumn{6}{|c|}{ Kategoria spoleczno-zawodowa } & \\
\hline & $\begin{array}{l}\text { Bezro- } \\
\text { botny }\end{array}$ & $\begin{array}{c}\text { Pracownik } \\
\text { fizyczny }\end{array}$ & $\begin{array}{c}\text { Pracownik } \\
\text { fizyczno- } \\
\text { umyslowy }\end{array}$ & $\begin{array}{c}\text { Pracownik } \\
\text { umyslowy }\end{array}$ & $\begin{array}{l}\text { Emeryt/ } \\
\text { rencista }\end{array}$ & $\begin{array}{l}\text { Uczeń/ } \\
\text { student }\end{array}$ & \multirow{4}{*}{$\begin{array}{c}\text { chi-kwa- } \\
\text { drat }=67,99 ; \\
d f=5 ; \\
\text { p }<0,05 ; \\
\text { V-Crame- } \\
\text { ra }=0,27\end{array}$} \\
\hline $\begin{array}{l}\text { Wyborcy } \\
\text { inkumbenta }\end{array}$ & \begin{tabular}{|c|}
$62,86 \%$ \\
$(\mathrm{n}=22)$
\end{tabular} & $\begin{array}{l}51,24 \% \\
(\mathrm{n}=62)\end{array}$ & $\begin{array}{l}56,63 \% \\
(\mathrm{n}=47)\end{array}$ & $\begin{array}{l}40,82 \% \\
(n=129)\end{array}$ & $\begin{array}{l}67,70 \% \\
(\mathrm{n}=218)\end{array}$ & $\begin{array}{c}24,14 \% \\
(\mathrm{n}=14)\end{array}$ & \\
\hline \begin{tabular}{|l|} 
Wyborcy \\
pretendentów
\end{tabular} & $\begin{array}{c}37,14 \% \\
(n=13)\end{array}$ & $\begin{array}{l}48,76 \% \\
(n=59)\end{array}$ & $\begin{array}{l}43,37 \% \\
(n=36)\end{array}$ & $\begin{array}{l}59,18 \% \\
(n=187)\end{array}$ & $\begin{array}{l}32,30 \% \\
(n=104)\end{array}$ & $\begin{array}{c}75,86 \% \\
(n=44)\end{array}$ & \\
\hline Razem & $100 \%$ & $100 \%$ & $100 \%$ & $100 \%$ & $100 \%$ & $100 \%$ & \\
\hline
\end{tabular}

* Na podstawie pytania zamieszczonego w sondażu z drugiej tury wyborów. Wyniki nie obejmują zatem reprezentacji osób, które nie udały się do drugiej tury wyborów.

Źródło: Badania własne exit poll 2006 i 2014. W analizie nie uwzględniono braków danych.

W przypadku relacji między wiekiem a poparciem w wyborach inkumbenta warto zwrócić szczególną uwagę na najstarszą kategorię wiekową. Jest to bowiem zbiorowość wyborców, której preferencje w największym stopniu uległy zmianie na przestrzeni dwóch analizowanych elekcji w Bielsku-Białej. W 2006 roku w zbiorowości wyborców w wieku eme- 
rytalnym inkumbent cieszył się najmniejszym poparciem z wszystkich kategorii wiekowych (choć należy zaznaczyć, że większość wyborców w wieku emerytalnym i tak popierała w tej elekcji inkumbenta), podczas gdy w roku 2014 poparcie to było największe z wszystkich grup wiekowych. Trudno jednoznacznie odpowiedzieć na pytanie o przyczyny tej zmiany. Można jednak zaproponować dwa wyjaśnienia tego zjawiska.

W roku 2006 względnie dużą część głosów wyborców w wieku emerytalnym zdobył kandydat PiS (było to $16,67 \%$, podczas gdy ,zdobycze” innych pretendentów nie przekraczały w tej grupie wiekowej $10 \%$ ). Jednak w roku 2014 profil wyborcy PiS-u na poziomie wybranej gminy uległ zmianie - PiS utracił swe wyraźnie senioralne oblicze, także poprzez wystawienie względnie młodego (trzydziestopięcioletniego) kandydata. Co więcej, w roku 2014 inkumbent miał 73 lata, mógł więc wydawać się odpowiednim kandydatem dla wyborców starszych, ale zdecydowanie mniej odpowiadał wyborcom młodszym - warto zwrócić uwagę na wyraźnie liniowy spadek poparcia dla inkumbenta wraz z wiekiem (patrz tabela 1, dane z 2014 roku).

Jest jednak również prawdopodobne, że zaobserwowane zmiany wynikają do pewnego stopnia $\mathrm{z}$ oczywistego przechodzenia poszczególnych roczników wyborców do starszych kategorii wiekowych i wymierania najstarszych kohort wyborców, w których inkumbent był mniej popularny.

Analiza społeczno-demograficznych uwarunkowań zachowań wyborczych ma niewatpliwe zalety praktyczne. Jest to również kanoniczny element opracowań opisujących zjawiska stanowiące przedmiot zainteresowania empirycznej socjologii i politologii. Należy jednak zwrócić uwagę, że badanie zachowań wyborczych w elekcji samorządowej na poziomie jednej gminy wyklucza szanse generalizacji wniosków na szerszą populację. To jak cechy społeczno-demograficzne wyborców warunkują poparcie określonych kandydatów w znacznym stopniu zależy bowiem od ich indywidualnych cech (np. wieku kandydata), od przyjętej przez nich formy kampanii wyborczej, a także od polityki lokalnych mediów (z kim sympatyzują i na jakiego odbiorcę są nastawione). Pod tym kątem każda gmina może być różna, a zatem różne zmienne społeczno-demograficzne w odmienny sposób będą wiązały się z głosowaniem na inkumbenta lub poparciem pretendenta/pretendentów w wyborach lokalnych.

Ogólniejszy charakter będą miały natomiast wnioski dotyczące zagadnień bardziej odseparowanych od lokalnej specyfiki, takich jak motywacje głosowania na kandydata ubiegającego się o reelekcję, a także 
związki między poparciem/odrzuceniem inkumbenta a poziomem wiedzy politycznej wyborców i ich postawą wobec zmian.

\section{Deklarowane motywy poparcia inkumbenta i ocena jego pracy jako prezydenta miasta}

Jak wcześniej wspomniano, uprzywilejowaną pozycję urzędujących polityków w wyborach próbuje się tłumaczyć większą rozpoznawalnością inkumbenta, która w naturalny sposób wynika z pełnienia urzędu, a także możliwościami kształtowania przez niego wydatków publicznych w taki sposób, by zdobyć aprobatę wyborców.

Rezultaty badań sondażowych exit poll z roku 2006 potwierdzają powyższe przypuszczenia. Analizy statystyczne ujawniają bowiem istotną statystycznie zależność między deklaracją motywu dokonań kandydata ${ }^{3}$ a wyborem inkumbenta (patrz tabela 3). Okazuje się, że wyborcy inkumbenta istotnie częściej niż wyborcy pretendentów wskazywali motyw dokonań kandydata, a spośród wszystkich kontrolowanych w badaniu powodów głosowania, to właśnie deklaracja motywu dokonań najsilniej warunkuje poparcie inkumbenta w wyborach (patrz wartości współczynnika V-Cramera w tabeli 3).

Znacznie słabsze, choć nadal istotne statystycznie, okazują się zależności między poparciem/odrzuceniem inkumbenta a deklaracją takich motywów głosowania jak: przynależność partyjna kandydata, osobista znajomość z kandydatem, program kandydata oraz motywacje sporadyczne, które połączono w jedną kategorię „inne motywy”" Wymienione wyżej powody głosowania częściej deklarowali przy tym wyborcy pretendentów, co pozwala na stwierdzenie, że elektoraty pretendentów w mniejszym stopniu kierują się tym, co kandydaci dotychczas zrobili w życiu politycznym ${ }^{5}$, natomiast $\mathrm{w}$ większym stopniu antycypują przyszłe działania swych kandydatów na podstawie programu lub afiliacji partyjnej. Dla wyborców inkumbenta najważniejsze są natomiast jego dotychczasowe

${ }^{3}$ Pytanie o motywy głosowania było półotwartym pytaniem wielokrotnego wyboru.

4 Kategoria inne motywy łączy w sobie deklaracje bardzo różnych powodów głosowania, takich jak m.in.: osobowość, losowanie kandydata, uczciwość, kompetencje, wykształcenie, wiek, przekonujące ulotki, etc.

${ }^{5}$ Choć może być to również szeroko rozumiane życie publiczne, np. dokonania w dziedzinie sztuki, gospodarki lub sportu. 
działania (lub wyobrażenia na temat takich działań) i to na ich podstawie antycypują oni przyszłe poczynania wybranego polityka.

Tabela 3

Motywy glosowania na prezydenta miasta w zbiorowości wyborców inkumbenta i pretendentów

\begin{tabular}{|c|c|c|c|c|c|c|}
\hline & \multicolumn{3}{|c|}{ Dokonania } & \multicolumn{3}{|c|}{ Przynależność partyjna } \\
\hline & Tak & Nie & Razem & Tak & Nie & Razem \\
\hline $\begin{array}{l}\text { Wyborcy } \\
\text { inkumbenta }\end{array}$ & $\begin{array}{l}77,38 \% \\
(\mathrm{n}=958)\end{array}$ & $\begin{array}{l}22,62 \% \\
(\mathrm{n}=280)\end{array}$ & $100 \%$ & $\begin{array}{l}13,81 \% \\
(\mathrm{n}=171)\end{array}$ & $\begin{array}{c}86,19 \% \\
(\mathrm{n}=1067)\end{array}$ & $100 \%$ \\
\hline \multirow[t]{4}{*}{$\begin{array}{l}\text { Wyborcy } \\
\text { pretendentów }\end{array}$} & $\begin{array}{l}24,51 \% \\
(\mathrm{n}=101)\end{array}$ & $\begin{array}{l}77,49 \% \\
(\mathrm{n}=311)\end{array}$ & $100 \%$ & $\begin{array}{l}43,20 \% \\
(\mathrm{n}=178)\end{array}$ & $\begin{array}{l}56,80 \% \\
(\mathrm{n}=234)\end{array}$ & $100 \%$ \\
\hline & \multicolumn{3}{|c|}{$\begin{array}{c}\text { chi-kwadrat }=345,85 ; \mathrm{df}=1 ; \mathrm{p}<0,05 ; \\
\text { V-Cramera }=0,48\end{array}$} & \multicolumn{3}{|c|}{$\begin{array}{c}\text { chi-kwadrat }=160,15 ; \mathrm{df}=1 ; \mathrm{p}<0,05 ; \\
\text { V-Cramera }=0,31\end{array}$} \\
\hline & \multicolumn{3}{|c|}{ Osobista znajomość } & \multicolumn{3}{|c|}{ Program } \\
\hline & Tak & Nie & Razem & Tak & Nie & Razem \\
\hline $\begin{array}{l}\text { Wyborcy } \\
\text { inkumbenta }\end{array}$ & $\begin{array}{l}5,98 \% \\
(n=74)\end{array}$ & $\begin{array}{c}94,02 \% \\
(\mathrm{n}=1164)\end{array}$ & $100 \%$ & $\begin{array}{l}29,89 \% \\
(\mathrm{n}=370)\end{array}$ & $\begin{array}{l}70,11 \% \\
(\mathrm{n}=868)\end{array}$ & $100 \%$ \\
\hline \multirow[t]{4}{*}{$\begin{array}{l}\text { Wyborcy } \\
\text { pretendentów }\end{array}$} & $\begin{array}{l}14,32 \% \\
(\mathrm{n}=59)\end{array}$ & $\begin{array}{l}85,68 \% \\
(\mathrm{n}=353)\end{array}$ & $100 \%$ & $\begin{array}{l}40,29 \% \\
(\mathrm{n}=166)\end{array}$ & $\begin{array}{l}59,71 \% \\
(\mathrm{n}=246)\end{array}$ & $100 \%$ \\
\hline & \multicolumn{3}{|c|}{$\begin{array}{c}\text { chi-kwadrat }=19,03 ; \mathrm{df}=1 ; \mathrm{p}<0,05 ; \\
\text { V-Cramera }=0,13\end{array}$} & \multicolumn{3}{|c|}{$\begin{array}{c}\text { chi-kwadrat }=15,26 ; \mathrm{df}=1 ; \mathrm{p}<0,05 ; \\
\text { V-Cramera }=0,10\end{array}$} \\
\hline & \multicolumn{3}{|c|}{ Kategoria: Inne motywy } & & & \\
\hline & Tak & Nie & Razem & & & \\
\hline $\begin{array}{l}\text { Wyborcy } \\
\text { inkumbenta }\end{array}$ & $\begin{array}{l}3,88 \% \\
(\mathrm{n}=48)\end{array}$ & $\begin{array}{c}96,12 \% \\
(n=1190)\end{array}$ & $100 \%$ & & & \\
\hline \multirow[t]{2}{*}{$\begin{array}{l}\text { Wyborcy } \\
\text { pretendentów }\end{array}$} & $\begin{array}{l}\begin{array}{l}10,19 \% \\
(\mathrm{n}=42)\end{array} \\
\end{array}$ & $\begin{array}{l}89,81 \% \\
(\mathrm{n}=370)\end{array}$ & $100 \%$ & & & \\
\hline & \multicolumn{3}{|c|}{$\begin{array}{c}\text { chi-kwadrat }=23,92 ; \mathrm{df}=1 ; \mathrm{p}<0,05 ; \\
\text { V-Cramera }=0,12\end{array}$} & & & \\
\hline
\end{tabular}

Źródło: Badania własne exit poll 2006. W analizie nie uwzględniono braków danych.

Analiza motywów głosowania w wyborach prezydenta miasta pozwala również na ocenę skuteczności poparcia, jakie formalnie bezpartyjny inkumbent może uzyskać ze strony partii politycznej. Co zrozumiałe, wyborcy inkumbenta, który utworzył własny bezpartyjny komitet wyborczy rzadziej niż wyborcy pretendentów (z których niektórzy reprezentowali komitety partii politycznych) wskazywali przynależność partyjną jako powód głosowania. Warto jednak zauważyć, że część z wyborców 
inkumbenta (blisko 14\%), pomimo jego formalnej bezpartyjności, traktowała go jako reprezentanta partii politycznej. Skromne eksponowanie poparcia udzielonego przez ugrupowanie polityczne jest zatem dobra strategią w przypadku tzw. kandydatów niezależnych, a przynajmniej bezpartyjnych inkumbentów - wyborcy niechętni partiom politycznym widzą wtedy w kandydacie osobę anty-partyjną (co pozwala na zdyskontowanie anty-partyjnych resentymentów), natomiast wyborcy ugrupowania popierającego inkumbenta widzą w nim kandydata partyjnego, a konkretnie kandydata partii, z którą sympatyzują.

Znaczenie poparcia partyjnego w wyborach lokalnych potwierdza jednak nie tylko badanie motywacji głosowania, ale także analiza, pozornie niezwiązanego z kwestią poparcia partyjnego, zagadnienia relacji między głosowaniem na inkumbenta a oceną jego dotychczasowej pracy. Szczegółowe dane w tabeli 4.

Tabela 4

Ocena pracy inkumbenta w zbiorowości wyborców inkumbenta i pretendentów

\begin{tabular}{||l|c|c|c|c||}
\hline \multirow{2}{*}{} & \multicolumn{4}{|c|}{ Ocena pracy inkumbenta jako prezydenta miasta } \\
\cline { 2 - 5 } & Źle & Średnio & Dobrze & Razem \\
\hline Wyborcy inkumbenta & $\begin{array}{c}0,33 \% \\
(\mathrm{n}=4)\end{array}$ & $\begin{array}{c}13,67 \% \\
(\mathrm{n}=167)\end{array}$ & $\begin{array}{c}86,00 \% \\
(\mathrm{n}=1051)\end{array}$ & $100 \%$ \\
& $\begin{array}{c}22,65 \% \\
(\mathrm{n}=87)\end{array}$ & $\begin{array}{c}53,13 \% \\
(\mathrm{n}=204)\end{array}$ & $\begin{array}{c}24,22 \% \\
(\mathrm{n}=93)\end{array}$ & $100 \%$ \\
\hline Wyborcy pretendentów & &
\end{tabular}

Źródło: Badania własne exit poll 2006. W analizie nie uwzględniono braków danych.

Jak można było przypuszczać, przeprowadzone analizy ujawniły istotną statystycznie i zarazem znaczną jak na warunki nauk społecznych, zależność między oceną pracy inkumbenta a oddaniem na niego głosu lub poparciem któregoś z pretendentów (chi-kawdrat $=610,63 ; \mathrm{df}=2 ; \mathrm{p}<0,05$; V-Cramera $=0,62)^{6}$. To, że wyborcy inkumbenta w zdecydowanej większości dobrze oceniali jego dotychczasową pracę $w$ roli prezydenta miasta, podczas gdy wyborcy pretendentów w swych ocenach byli bardziej sceptyczni nie jest zaskoczeniem. O wiele bardziej zaskakujący jest fakt, że choć blisko 14\% wyborców inkumbenta oceniło jego dotychczasową pracę jako „średnią”, to i tak zdecydowało się na niego zagłosować. W tym przypadku duże znaczenie okazuje się mieć fakt poparcia inkumbenta przez partię polityczną. Analizy wykazały, że 24,55\% wyborców oceniających pracę inkumbenta jako śred-

\footnotetext{
${ }^{6} \mathrm{~W}$ analizie nie uwzględniono odpowiedzi „nie mam zdania”.
} 
nią deklarowało motyw przynależności partyjnej jako przyczynę udzielenia mu poparcia, podczas gdy w zbiorowości osób oceniających tę pracę jako dobrą przynależnością partyjną kierowało się o połowę mniej wyborców, tj. $11,81 \%$ (wskazane różnice są istotne statystycznie: chi-kwadrat $=19,96, \mathrm{df}=1$; $\mathrm{p}<0,05$; V-Cramera $=0,13)^{7}$. Tak więc, uzyskanie poparcia partii politycznej może być istotnym czynnikiem decydującym o reelekcji na poziome wyborów lokalnych, gdyż podnosi szansę głosowania na inkumbenta nawet wtedy, gdy jego praca jest oceniania jako niezbyt dobra.

\section{Wiedza na temat specyfiki samorządu lokalnego, znajomość lokalnej sceny wyborczej i znajomość lokalnej polityki a głosowanie na inkumbenta}

Pytanie o to, czy poziom wiedzy politycznej wyborców inkumbenta różni się od poziomu wiedzy prezentowanej przez elektorat pretendentów jest w zasadzie pytaniem o to, czy głosowanie za reelekcją nie jest, w niektórych przypadkach, zachowaniem bezrefleksyjnym, a deklarowane powody głosowania są jedynie sposobem racjonalizacji nieprzemyślanych decyzji wyborczych. Głosowanie na inkumbenta może przecież służyć redukcji intelektualnych kosztów związanych z poszukiwaniem rzetelnych informacji na temat kandydatów, jak również być sposobem na pokrycie deficytu wiedzy o procesach zachodzących na lokalnej scenie politycznej, jej uczestnikach oraz dotychczasowej praktyce rządzenia pewnym obszarem administracyjnym, w tym przypadku gminą.

W zrealizowanych w roku 2006 i w roku 2014 badaniach exit poll wiedzę wyborców diagnozowano w oparciu o różne baterie wskaźników. W 2006 roku była to wiedza, którą można nazwać wiedzą na temat specyfiki samorządu lokalnego. Mierzono ją indeksem o wartości od 0 do 7 , na który złożyły się pytania o liczbę radnych w gminie oraz podległość prezydentowi miasta wybranych instytucji znajdujących się w mieście, takich jak: szkoły podstawowe, komenda policji, miejskie biblioteki, urzędy skarbowe, ośrodki pomocy społecznej oraz miejski zarząd komunikacji. Dodatkowo, obok wiedzy na temat specyfiki samorządu lokalnego w badaniu z roku 2006 diagnozowano również poprawność identyfikacji kandydatów wybieranych przez respondenta w wyborach do rady

${ }^{7} \mathrm{Z}$ analizy usunięto kategorię „oceniam źle”, gdyż liczyła ona tylko cztery osoby ( 2 z nich deklarowały motyw przynależności partyjnej, dwie pozostałe nie deklarowały tego motywu). 
miasta, co można potraktować jako wskaźnik znajomości lokalnej sceny wyborczej ${ }^{8}$.

W roku 2014 diagnozowano wiedzę, którą można nazwać znajomością lokalnej polityki. Do tego celu stworzono indeks, na który składały się pytania o nazwisko przewodniczącego rady miasta, nazwisko przynamniej jednego radnego z dzielnicy respondenta oraz pytanie o wysokość budżetu miasta. Tak skonstruowany indeks przybierał wartość od 0 do 3 .

Hipotezy, w myśl których głosowanie na inkumbenta powiązane będzie z mniejszą znajomością specyfiki samorządu lokalnego, niższą wiedzą na temat lokalnej sceny wyborczej lub mniejszą orientacją w lokalnej polityce muszą zostać odrzucone. Analizy danych zebranych w 2006 i 2014 roku nie ujawniają bowiem różnic między wyborcami inkumbenta a wyborcami pretendentów pod kątem analizowanych zmiennych (wyniki testów są nieistotne statystycznie).

Na marginesie warto zaznaczyć, że zarówno wiedza na temat samorządu lokalnego, znajomość lokalnej sceny wyborczej, jak i orientacja w lokalnej polityce nie są wysokie. W roku 2006 średnia indeksu wiedzy wyborców na temat specyfiki samorządu wynosiła 3,58 (możliwy zakres od 0 do 7$)$, a ponad połowa badanych $(52,30 \%)$ błędnie identyfikowała kandydatów, na których oddała głos w wyborach radnych gminnych. W roku 2014 średnia indeksu orientacji w lokalnej scenie politycznej wynosiła natomiast 0,38 (możliwy zakres od 0 do 3 ).

\section{Niechęć wobec zmian a głosowanie na inkumbenta}

Przed przystapieniem do prezentacji wyników na temat związków między nastawieniem wyborców wobec zmian a reelekcją należy z kronikarskiego obowiązku podkreślić, że problem osobowościowych uwarunkowań głosowania na inkumbenta zainteresował nie tylko autora niniejszego artykułu. Dotychczas ukazały się przynajmniej dwa artykuły, w których zbadano ujemne związki między poziomem tolerancji ryzyka a głosowaniem za reelekcją. W przypadku obu artykułów udowodniono, że

8 Za odpowiedź poprawną uznawano skojarzenie nazwiska z komitetem (ew. partią polityczna), a także właściwe przyporządkowanie kandydata do wyborów. Jeżeli wyborca podawał poprawnie nazwisko kandydata i komitet, ale odpowiadał, że ten kandydat startował w wyborach do sejmiku wojewódzkiego zamiast do rady gminy (lub odwrotnie), wtedy taką odpowiedź także klasyfikowano jako błędną. Jeżeli respondent podał tylko komitet lub tylko kandydata odpowiedź także uznawano za błędną. 
osoby mniej skłonne do podejmowania ryzyka częściej głosują na inkumbentów (Eckles, Schaffner, 2010; Eckles, Kam, Maestras, Schaffner, 2014).

Oczywiście nastawienie do ryzyka nie jest tożsame z nastawieniem wobec zmian, toteż wniosków z tego zakresu nie można porównywać wprost. Można je jednak traktować jako uzupełniające się.

Postawę wobec zmian diagnozowano w badaniu z 2014 roku za pomocą indeksu, którego wartość (od 0 do 4) wyznaczał stosunek wobec czterech następujących twierdzeń: 1) „Generalnie zmiany są czymś pozytywnym”; 2) „Znane jest zawsze lepsze od nieznanego”; 3) „Należy doświadczać nowości w swoim życiu”; 4) „Lepiej jest ronić te same rzeczy niż próbować czegoś nowego".

Jak wykazały analizy poziom ogólnej niechęci wobec zmian istotnie pod względem statystycznym, choć niezbyt silnie (patrz wartość współczynnika eta ${ }^{2}$ ), odróżnia wyborców inkumbenta od wyborców, którzy nie udzielili mu poparcia, a większą niechęć wobec zmian wykazują wyborcy opowiadający się za reelekcją (szczegółowe dane i wyniki testów statystycznych przedstawiono w tabeli 5).

Tabela 5

Natężenie niechęci wobec zmian a glosowanie na inkumbenta

\begin{tabular}{|c|c|c|c|c|c|}
\hline $\begin{array}{c}\text { Rok } 2014 \\
\text { II tura }\end{array}$ & $\begin{array}{c}\text { Wartość indeksu } \\
\text { niechęci wobec } \\
\text { zmian }(0-4)\end{array}$ & $\begin{array}{l}\text { Odchyle- } \\
\text { nie stan- } \\
\text { dardowe }\end{array}$ & $\begin{array}{c}\begin{array}{c}\text { Wspólczyn- } \\
\text { nik zmien- } \\
\text { ności }\end{array} \\
\end{array}$ & \begin{tabular}{|c|} 
Liczba \\
przypad- \\
ków
\end{tabular} & \multirow{3}{*}{$\begin{array}{c}\mathrm{F}[1 ; 1045]= \\
=65,77 ; \\
\mathrm{p}<0,05 \\
\text { eta }^{2}=0,06\end{array}$} \\
\hline Wyborcy inkumbenta & 1,06 & 0,79 & 0,75 & 605 & \\
\hline Wyborcy pretendenta & 0,68 & 0,72 & 1,05 & 442 & \\
\hline $\begin{array}{l}\text { Rok } 2014 \\
\text { I tura* }\end{array}$ & \begin{tabular}{|} 
Wartość indeksu \\
niechęci wobec \\
zmian (0-4)
\end{tabular} & $\begin{array}{l}\text { Odchyle- } \\
\text { nie stan- } \\
\text { dardowe }\end{array}$ & $\begin{array}{l}\text { Współczyn- } \\
\text { nik zmien- } \\
\text { ności }\end{array}$ & \begin{tabular}{|c|} 
Liczba \\
przypad- \\
ków
\end{tabular} & \multirow[t]{3}{*}{$\begin{array}{c}\mathrm{U}=76533,50 \\
\mathrm{p}<0,05^{* *}\end{array}$} \\
\hline Wyborcy inkumbenta & 1,11 & 0,75 & 0,68 & 494 & \\
\hline Wyborcy pretendentów & 0,72 & 0,77 & 1,06 & 432 & \\
\hline
\end{tabular}

* Na podstawie pytania zamieszczonego w sondażu z drugiej tury wyborów. Wyniki nie obejmują zatem reprezentacji osób, które nie udały się do drugiej tury wyborów.

** Test U Manna-Whitneya zastosowano ze względu na heterogeniczność wariancji w obu podgrupach.

Źródło: Badania własne exit poll 2014. W analizie nie uwzględniono braków danych.

${ }^{9}$ Odpowiedziom „Zgadzam się” i „Raczej się zgadzam” w przypadku twierdzenia nr 2 i nr 4 przypisano wartość 1 (pozostałym odpowiedziom przyporządkowano wartość 0 ), natomiast w przypadku twierdzeń $\mathrm{nr} 1$ i $\mathrm{nr} 3$ wartość 1 przypisano odpowiedziom „Nie zgadzam się” i „Raczej się nie zgadzam” 1 (pozostałym odpowiedziom przyporządkowano wartość 0 ). 
W związku z tym, że analizy wykazały istotną pod względem statystycznym korelację między wiekiem a wartością indeksu niechęci wobec zmian $(r=0,30 ; p<0,05)$ sprawdzono, czy zaprezentowane wyżej zależności faktycznie występują, czy też są one jedynie efektem różnic wiekowych między elektoratami. W tym celu przeprowadzono analizę kowariancji, uwzględniając wiek jako zmienną towarzyszącą (wiek został określony na podstawie pytania o rok urodzenia). Także w tym przypadku zaobserwowane wcześniej zależności okazały się istotne pod względem statystycznym $(\mathrm{F}[1 ; 1037]=35,85 ; \mathrm{p}<0,05$ - dla drugiej tury i $F[1 ; 917]=31,02 ; p<0,05-$ dla tury pierwszej).

Można zatem powiedzieć, że w wyścigu o władzę inkumbentowi sprzyja nie tylko fakt spełniania urzędu (co implikuje jego większą rozpoznawalność i pomaga mu w zbudowaniu pozytywnego wizerunku), ale także zachowawcza postawa części obywateli. W kontekście zachowań wyborczych obywateli reelekcja ma zatem również swój psycho-społeczny (osobowościowy) wymiar.

\section{Podsumowanie}

Najważniejsze wnioski, jakie nasuwają się po analizie materiału empirycznego dostarczonego badaniami exit poll można zawrzeć w trzech punktach.

Po pierwsze, dla wyborców najważniejszą motywacją głosowania na inkumbentów są ich dokonania lub wyobrażenia na ten temat. W ten sposób, wcześniejsze przypuszczenia badaczy o uprzywilejowanej pozycji urzędujących polityków w wyborach znalazły swe potwierdzenie w deklaracjach głosujących.

Po drugie, nie ma różnic między wyborcami inkumbentów a wyborcami pretendentów w zakresie wiedzy, a właściwie niewiedzy, na temat lokalnej polityki. Decyzja, kogo wybrać na włodarza gminy musi być zatem w przypadku większości głosujących podejmowana na podstawie kwestii wizerunkowych a nie w oparciu o dogłębną analizę popartą znajomością lokalnej polityki oraz zakresu kompetencji poszczególnych organów władz samorządowych.

Po trzecie, głosowanie za reelekcją urzędującego polityka lub przeciw niej jest nie tylko wynikiem wyobrażeń (rzadziej wiedzy) na temat dokonań kandydatów, ich programów, afiliacji partyjnych, etc., lecz jest, do pewnego stopnia, również konsekwencją jednej z cech osobowościowych, jaką jest poziom niechęci do zmian. 
W świetle przytoczonych obserwacji, o ile nie zmienią się regulacje prawne w kwestii kadencyjności, długie rządy wybieranych na kolejne kadencje prezydentów/burmistrzów lub wójtów wydają się nieuniknione. Pytanie o to, czy jest to złe, czy też dobre dla finansów gmin, mieszkańców i lokalnego życia politycznego ciagle czeka na potwierdzoną badaniami empirycznymi jednoznaczną odpowiedź.

\section{Bibliografia}

Ansolabehere S., Snyder J. M. Jr., Stewart Ch. (2000), Old Voters, New Voters, and the Personal Vote: Using Redistricting to Measure the Incumbency Advantage, „American Journal of Political Science”, vol. 44, nr 1.

Bartels L. M. (1996), Uninformed Votes: Information Effects in Presidential Elections, „American Journal of Political Science”, vol. 40, nr 1.

Bartnicki S. (2014), Lokalna egzekutywa u progu czwartej kadencji wyborów bezpośrednich. Wnioski z analizy ilościowej, „e-Politicon”, nr 11.

Brender A. (2003), The effect of fiscal performance on local government election results in Israel: 1989-1998, ,Journal of Public Economics”, vol. 87, nr 9-10.

Brender A., Drazen A. (2008), How Do Budget Deficits and Economic Growth Affect Reelection Prospects? Evidence from a Large Panel of Countries, „American Economic Review", vol. 98, nr 5.

Bukowski M., Flis J., Hess A., Szymańska A. (2011), Opcja czy osoba? Upartyjnienie versus personalizacja $w$ wyborach samorzadowych, Wydawnictwo Uniwersytetu Jagiellońskiego, Kraków.

Caseette A., Farvaque E. (2014), Are Elections Debt Brakes? Evidence from French Municipalities, „Economics Letters”, vol. 122, nr 2.

Cox G. W., Morgenstern S. (1993), The Increasing Advantage of Incumbency in the U.S. States, „Legislative Studies Quarterly”, vol. 18, $\mathrm{nr} 4$.

Cox G. W., Morgenstern S. (1995), The Incumbency Advantage in Multimember Districts: Evidence from the U.S. States, „Legislative Studies Quarterly”, vol. 20, nr 3.

Eckles D. L., Kam C. D., Maestas Ch. D., Schaffner B. F. (2014), Risk Attitudes and the Incumbency Advantage, „Political Behavior”, vol. 36, nr 4.

Eckles D. L., Schaffner B. F. (2010), Risk Aversion and the Incumbency Advantage, http://people.umass.edu/schaffne/incumbent_riskaversion_final.pdf.

Erikson R. S. (1971), The Advantage of Incumbency in Congressional Elections, „Polity", vol. 3, nr 3 .

Gendźwiłł A. (2008), Dlaczego sukces? Analiza wyników wyborów prezydentów największych polskich miast, w: Studia nad wyborami. Polska 2005-2006, red. J. Raciborski, Wydawnictwo Naukowe Scholar, Warszawa.

Hyneman Ch. S. (1938), Tenure and Turnover of Legislative Personnel, „Annals of the American Academy of Political and Social Science", nr 195, January. 
King G. (1991), Constituency Service and Incumbency Advantage, „British Journal of Political Science", vol. 21, nr 1.

Kozielecki J. (1986), Erozja władzy: anatomia zjawiska, „Studia Socjologiczne”, nr 2.

Kubisz-Muła Ł. (2013), Badanie exit poll - historia, funkcje i specyfika, „Studia Socjologiczne", $\mathrm{nr} 4$.

Levitt S. D., Wolfram C. D. (1997), Decomposing the Sources of Incumbency Advantage in the U.S. House, „Legislative Studies Quarterly”, vol. 22, nr 1.

Mann T. E., Wolfinger R. E. (1980), Candidates and Parties in Congressional Elections, ,The American Political Science Review”, vol. 74, nr 3.

Mayhew D. R. (1974), Congressional Elections: The Case of the Vanishing Marginals, „Polity”, vol. 6, nr 3.

Piechota G. (2013), Źródła poparcia wyborczego lokalnych liderów w samorzqdowych kampaniach wyborczych (na przykładzie kampanii wyborczych prezydentów miast na prawach powiatu w 2010 roku), ,Środkowoeuropejskie Studia Polityczne", nr 2.

Rutkowski P. (2008), Klientelizm w perspektywie wyborów samorzqdowych - studium miasta średniej wielkości. Hipoteza klientystyczna jako próba wyjaśnienia ,fenomenu reelekcji”, w: Studia nad wyborami. Polska 2005-2006, red. J. Raciborski, Wydawnictwo Naukowe Scholar, Warszawa.

Sakurai S., Menezes-Filho N. (2008), Fiscal policy and reelection in Brazilian municipalities, „Public Choice”, vol. 137, nr 1-2.

Tybuchowska-Hartlińska K. (2012), Wybory do samorzadu terytorialnego w Polsce. Dwadzieścia lat doświadczeń w subregionie ciechanowskim, Europejskie Centrum Edukacyjne, Toruń.

Veiga L. G., Veiga F. J. (2007), Does opportunism pay off?, „Economics Letters”, vol. 96, nr 2 .

\section{The city mayor reelection phenomenon in view of exit poll surveys from Bielsko-Biała}

\section{Summary}

The aim of the article is to indicate determinants of, so called, city mayors reelection phenomenon by using survey methodology. The article is based on two exit poll surveys' data, conducted in $2006(n=1769)$ and in $2014(n=1160)$.

The analysis has shown statistically significant relationships between voting for an incumbent and some socio-demographical variables (such as age and socio-economic status), voting motivations (particularly motives of candidates' accomplishments) and intensity of one of socio-psychological human being feature which is an aversion toward changes. The evidence that voting for reelection correlates with the level of personal political knowledge has not been found.

Key worlds: reelection, local elections, election behavior 